\title{
Small Intestinal Tubular Adenoma
}

National Cancer Institute

\section{Source}

National Cancer Institute. Small Intestinal Tubular Adenoma. NCI Thesaurus. Code C43552.

A usually polypoid neoplasm that arises from the glandular epithelium of the small intestine. It is characterized by a tubular architectural pattern. The neoplastic glandular cells have dysplastic features. 